\title{
Historical decline and probable extinction of the Jamaican Golden Swallow Tachycineta euchrysea euchrysea
}

\author{
GARY R. GRAVES
}

\begin{abstract}
Summary
The endemic Jamaican subspecies of the Golden Swallow Tachycineta euchrysea euchrysea has been rare and locally distributed since its discovery in 1847 . By the 1950s, its geographic range had contracted to a small region along the northern frontier of Cockpit Country. The last unequivocal sight records occurred in the early 1980s, raising strong concern about the swallow's conservation status. I conducted an island-wide search for the swallow from 1994 through 2012. Standardised censuses of aerial insectivores at 1,281 sites, including the last redoubts of the Golden Swallow in Trelawny Parish, revealed no evidence of the species. These surveys and the absence of documented sight records during the past three decades suggest that the Jamaican race of the Golden Swallow is close to extinction if not already extinct. The cause of the population decline is unknown but is most likely linked to chronic predation by introduced mammalian predators, particularly the arboreal black rat Rattus rattus.
\end{abstract}

\section{Introduction}

The Golden Swallow Tachycineta euchrysea, one of the rarest and arguably the most beautiful species in the family Hirundinidae, is endemic to Jamaica and Hispaniola in the West Indies (Bond 1936, 1956). The Hispaniolan subspecies T. e. sclateri was reported to be locally common in the highlands of Hispaniola as late as the 1920s (Wetmore and Swales 193I) but is currently considered to be an uncommon and increasingly rare permanent resident of pine and broadleaf forests, usually at altitudes $>750 \mathrm{~m}$ in the Cordillera Central, Sierra de Neiba, and Sierra de Bahoruco in the Dominican Republic and in Massif de la Hotte and Massif de la Selle in Haiti (Keith et al. 2003, Townsend et al. 2008). In contrast, the Jamaican subspecies (Tachycineta e. euchrysea) has always been uncommon to rare and locally distributed since its discovery in 1847 . The following summary of the distribution and abundance of Jamaican populations provides historical context for the recent search for the Jamaican Golden Swallow.

\section{Historical records of the Golden Swallow in Jamaica}

The Golden Swallow was unknown to the earliest English naturalists in Jamaica (Sloane 1725, Browne 1756). Most of what is known about its behaviour and nesting biology was published in four mid-1 $19^{\text {th }}$ century sources that deserve wider notice in current conservation studies of Caribbean birds (Gosse 1847, Osburn 1859a, b, 1860). Philip Henry Gosse, who described the species, provided the first information on its distribution (Gosse 1847: 68): 
"This exceedingly lovely little Swallow, whose plumage reflects the radiance of the Hummingbirds, is found, as I am informed by Mr. Hill, in the higher mountains formed by the limestone range of the very centre of the island, as in Manchester, and St. Ann's. It is not until we ascend this central chain, that we meet with this sweet bird, occasionally in the more open dells, but principally confined to the singular little glens called cockpits."

The most comprehensive behavioural observations were made by William Osburn on the northern frontier of Cockpit Country in north-western Jamaica during October and November 1858 (Osburn 1859a). Small groups and a few larger flocks numbering "two to three hundred" were observed foraging low over sugarcane fields, meadows, clumps of bamboo, and the crowns of bread-nut trees Brosimum alicastrum at Mahogany Hall (245 m asl), Trelawny Parish $\left(874 \mathrm{~km}^{2}\right)$. Swallow abundance fluctuated with the passage of weather fronts (Osburn 1859a: 6372):

"As far as my observations go, there seems, in one or two points, a similarity between the habits of this swallow and the great swift [Streptoprocne zonaris]: neither are constant inhabitants of the limestone valleys midway between the coast and the central ridge; both appear during wet weather in large flocks, not so intent on feeding as apparently going over their hunting-grounds, and afterwards, for some days after the bad weather, hawking in flocks of much reduced numbers, as usual with the family."

In April 1859, Osburn visited Freeman's Hall (450 m), Trelawny Parish, and found that the flocks of swallows had dispersed and that the birds had paired (Osburn $1859 \mathrm{~b}$ ). One pair that frequently entered an old sugarcane boiling-house was suspected of breeding but Osburn failed to find the nest. Some months later, Osburn recorded the sole nesting record for Jamaica (Osburn 1859b: 6721):

"I observed another pair constantly at a particular part of the road which passes through the German settlement here; but the houses were all low, and evidently not inhabited by them. Wishing to shoot one, I stopped to watch them, and then noticed they often disappeared among some bushes on a steep hill-side. I sent to examine the spot, and my expectations were considerably raised on hearing there was a cave. A pair flew round on my approaching the aperture, in evident alarm; and, concealing myself, after long waiting, I discovered they entered a small crevice in the limestone in the interior of the cave. The aperture was just large enough to admit the hand; but to my disappointment there were then ( $19^{\text {th }}$ July) three young. They were naked and blind, the skin of a slate-gray colour. The nest, of which the hollow was not more than three-quarters of an inch deep, was a structure of considerable art. The interior was lined with a bed of the softest silk-cotton, intermingled with feathers, among which those of a green parrot were conspicuous. The foundation and external portions were composed of a flocculent substance; what it is I am not sure, unless it be silk-cotton picked off the ground, and strengthened by intermingled soil and bits of trash. With this is mixed the pappus of, I suspect, Compositae and Tillandsiae, but the seeds are broken off. The whole mass is intertwined with bits of Lycopodium, which, though very ornamental, is extraordinary, as in the narrow deep hole it could not add to the concealment as in an exterior nest. The diameter was about 5 inches, the outside depth $13 \frac{3}{4}$ inch. It was the only nest, apparently, in the cave." 
The Jamaican race of the Golden Swallow is known from 31 specimens (Table 1), of which II have restrictive locality data (place name). One of Osburn's specimens (National Museum of Natural History, USNM 23333), collected in "Trelawny" on 19 July 1859, may have been one of the pair associated with the nest discovered at Freeman's Hall. Another specimen (USNM 30284), supposedly collected in July 1863 by William T. March at Spanish Town, St. Catherine Parish (March 1863), was probably taken elsewhere (p. 295): "I have not yet had an opportunity of noting this species, I have only met with two indifferent specimens; they are, I am informed, to be found at Content, in Manchester [Parish], where they form a colony in an old building also occupied by the H. fulva [= Petrochelidon fulva, Cave Swallow]". In unpublished correspondence to Spencer F. Baird, dated 4 April 1864 (Smithsonian Institution Archives. Record Unit 305, Accession 477), March added, "I have during this visit been able to add St. Ann and St. Mary that is the central range of hills as the habitat of the Golden Swallow, I found it, there as in Manchester in [c]ompany with the P. fulva - one of my sons now at Walton will look out for specimens - the White-Collared Swift is also there".

Table 1. Known specimens of Jamaican Golden Swallow Tachycineta euchrysea euchrysea.

\begin{tabular}{|c|c|c|c|}
\hline Museum number & Location & Collector & Date \\
\hline $\mathrm{AMNH}_{40233}$ & Jamaica & M. J. Heade & $?$ \\
\hline BMNH $1847 \cdot 6.8 .16$ (type) & Jamaica & R. Hill & $?$ \\
\hline BMNH 1858.10 .1 .18 & Jamaica & Capt. Hamilton & $?$ \\
\hline BMNH 1858.10 .1 .19 & Jamaica & Capt. Hamilton & $?$ \\
\hline BMNH $1884 \cdot 3 \cdot 24 \cdot 77$ & Jamaica & $?$ & $?$ \\
\hline BMNH 1884.5 .15 .66 & Jamaica & W. Osburn & $?$ \\
\hline BMNH 1884.5 .15 .67 & Jamaica & Ward & $?$ \\
\hline BMNH $1885 \cdot 3 \cdot 24 \cdot 76$ & Jamaica & Cutter & $?$ \\
\hline CU 9105 & Blue Mountains, $6000 \mathrm{ft}$ & L. A. Fuertes & 29 June 1904 \\
\hline FM 10871 & St George's, Portland Parish & $?$ & 6 June 1885 \\
\hline FM 10872 & St George's, Portland Parish & $?$ & 6 June 1885 \\
\hline FM 10873 & no location & $?$ & 1865 \\
\hline LM T12140 & Jamaica & E. Newton & $?$ \\
\hline LM T12141 & Jamaica & E. Newton & $?$ \\
\hline MCZ 120419 & Portland & J. E. Sherlock & 9 August 1908 \\
\hline $\mathrm{MCZ}_{12 \mathrm{O}} 2 \mathrm{O}$ & Portland & J. E. Sherlock & 9 August 1908 \\
\hline MCZ 82026 & St George's, Portland Parish & $?$ & 31 Мay 1884 \\
\hline $\mathrm{ROM}_{48354}$ & "Jamaica" & $?$ & $?$ \\
\hline UC $27 / \mathrm{Hir} / 8 / \mathrm{a} /{ }_{1}$ & [illegible] Gap, St. Andrew Parish & J. Goodlet & 26 May 1879 \\
\hline $\mathrm{UC} 27 / \mathrm{Hir} / 8 / \mathrm{a} / 2$ & [illegible] Gap, St. Andrew Parish & J. Goodlet & 27 May 1879 \\
\hline UC $27 / \mathrm{Hir} / 8 / \mathrm{a} / 3$ & Cinchona, St. Andrew Parish & J. Goodlet & 21 July 1879 \\
\hline UC $27 / \mathrm{Hir} / 8 / \mathrm{a} / 4$ & Cinchona, St. Andrew Parish & J. Goodlet & 22 July 1879 \\
\hline $\mathrm{UC} 27 / \mathrm{Hir} / 8 / \mathrm{a} / 5$ & Mt. Charles, St. Andrew Parish & J. Goodlet & 27 August 1879 \\
\hline UC $27 / \mathrm{Hir} / 8 / \mathrm{a} / 6$ & Mt. Charles, St. Andrew Parish & J. Goodlet & 1o September 1879 \\
\hline UC $27 / \mathrm{Hir} / 8 / \mathrm{a} / 7$ & Cinchona, St. Andrew Parish & D. Morris & 2nd week of March 1880 \\
\hline UC $27 / \mathrm{Hir} / 8 / \mathrm{a} / 8$ & Jamaica & $?$ & 1849 \\
\hline UC $27 / \mathrm{Hir} / 8 / \mathrm{a} / 9$ & Freeman's Hall, Trelawny Parish & W. Osburn & $?$ \\
\hline USNM 23333 & Freeman's Hall, Trelawny Parish & W. Osburn & 19 July 1859 \\
\hline USNM 30284 & "Spanishtown" & W. T. March & July 1863 \\
\hline USNM 80852 & Cinchona, St. Andrew Parish & D. Morris & 2nd week of March \\
\hline USNM 80853 & Cinchona, St. Andrew Parish & D. Morris & 2nd week of March \\
\hline
\end{tabular}

Abbreviations: AMNH (American Museum of Natural History); BMNH (Natural History Museum, formerly British Museum of Natural History); CU (Cornell University Museum of Vertebrates); FM (Field Museum); LM (National Museums Liverpool); MCZ (Museum of Comparative Zoology, Harvard University); UC (Cambridge University Museum of Zoology); USNM (National Museum of Natural History, Smithsonian Institution). 
Osburn (1860: 6877) observed the Golden Swallow in Manchester Parish in 1858 or 1859 near the "southern base of the central range at Oxford [210 m]." The only record of the Golden Swallow near sea level in Jamaica was reported from the vicinity of Agualta Vale (50 m), St. Mary Parish, (Osburn 186o: 6876):

"One of the points which have attracted my attention the most with regard to the birds of the district, I alluded to in my last letter, viz., the almost constant occurrence of flocks of Acanthylis [= Streptoprocne zonaris, White-collared Swift] along the coast, within the sound of the surf. With these I have also often noticed flocks of Hirundo [Tachycineta] euchrysea, similar to those observed last year at this season about Mahogany Hill."

All of Osburn's localities in Jamaica were much lower in altitude than documented breeding sites (1,000-1,425 m) in Hispaniola (Keith et al. 2003, Townsend et al. 2008). Osburn (1860: 6878) hypothesized that the swallow was an altitudinal migrant in Jamaica, breeding in the higher mountains during the summer months and moving to lower altitudes during the non-breeding season:

"I have given these observations in some detail, because they seem of more than mere theoretical importance. The case of a naturalist may easily be supposed whom circumstances led to the southern foot of the central range during the cold months. He might there see, one or twice, H. euchrysea [Tachycineta euchrysea], and procure specimens; he then might pass a whole year on the South coast, and even travel extensively on the North coast, without again falling in with them, and thus be led to conclude them to be stragglers from some external migration, when they really only travel up and down the mountains."

Golden Swallows in Hispaniola have also been recorded at altitudes well below the documented breeding zone during the post-breeding season (Wetmore and Swales 1931, Keith et al. 2003). However, historical records and contemporary accounts indicate that seasonal movements of Golden Swallow populations do not extend beyond the shorelines of Jamaica and Hispaniola. Extralimital records are unknown, even to the offshore islands of Hispaniola (Wetmore and Swales 1931, Keith et al. 2003).

The species was uncommon and locally distributed in the highlands of St. Andrew Parish above Kingston in the late $19^{\text {th }}$ century when a series of nine specimens were collected in the Port Royal Mountains at Cinchona, Mt. Charles, and [illegible] Gap (Table 1). However, W. E. D. Scott never encountered the Golden Swallow during his fieldwork and specimen collecting activities from November 1890 to March 1891 at Stony Gap, St. Andrew Parish, or at Boston, in the watershed of the Priestman's River, Portland Parish (Scott 1893, 1904). The last specimens collected in Jamaica were a pair obtained in "Portland" on 9 August 1908, and a female obtained by the artist, Louis Agassiz Fuertes, in the "Blue Mountains, 6,000 ft" on 29 June 1904.

Sight records by Ludlow Griscom were reported from the river gorge between Bog Walk and Ewarton in St. Catherine Parish (Bond 1940), the only such report between Trelawny and Manchester parishes to the west and St. Andrew and St. Mary parishes to the east since March's observations in 1864. Overall, the Golden Swallow has been reliably reported in only seven of the 14 Jamaican parishes (Manchester, Trelawny, St. Catherine, St. Ann, St. Mary, St. Andrew, Portland). There are no records for low rainfall areas $(<150 \mathrm{~cm} /$ year $)$ on the southern coastal plain.

The last unequivocal sighting from the Blue Mountains [St. Andrew or Portland parishes], was reported in 1950 (Bond 1956). By the 1960s, Windsor in Trelawny Parish, on the northern flank of Cockpit Country, was regarded as the most dependable location for the Golden Swallow 
in Jamaica (Kidd 1964, 1965). However, there have been no records from Windsor in the past 40 years. The last probable records in Jamaica with specified dates were reported in the Gosse Bird Club Broadsheet from the Barbecue Bottom Road, Trelawny Parish: (i) several were observed on 3 July 1972 (Downer and Sutton 1972); (ii) seven individuals were observed on 15 August 1982 (Sykes 1983), and (iii) six to nine individuals were observed on 11 September 1982 (Downer 1982). Robert Sutton and other observers failed to find the species on many subsequent trips to the Barbecue Bottom in the 1980s. From the 1960s through the 1980s, Golden Swallow sightings in Jamaica were regarded as birding highlights, but the conservation status of the Jamaican population was only then coming into focus (King 1981, Downer 1982). Consequently, sighting reports were casual, rarely mentioning more than location, date, and number of individuals. Moreover, none of the reports was rigorously documented by peer-reviewed publications or photographs, even though the superficially similar Tree Swallow Tachycineta bicolor, a regular winter visitor (Haynes-Sutton et al. 2009), and the Violet-green Swallow Tachycineta thalassina were reported during the same period in western Jamaica (Salmon 1964). The last reported sighting of the Golden Swallow in Jamaica was of three individuals on 8 June 1989 at Hardwar Gap, on the border between St. Andrew and Portland parishes (Sladen 1997), although this record must be regarded as questionable owing to the poor documentation and the possibility of confusion with other species of Tachycineta swallows. In summary, there have been no irrefutable records of Golden Swallow in Jamaica for more than 30 years.

The Jamaican subspecies of the Golden Swallow is considered as "Critically Endangered" (King 1981, Raffaele et al. 1998) and as "very rare, possibly extinct" (Haynes-Sutton et al. 2009). BirdLife International, the bird authority for the International Union for Conservation of Nature (IUCN), lists the swallow as "Probably Extinct" (BirdLife International 2013). Here I report the results of a comprehensive search for Jamaican populations of the Golden Swallow that extended from 1994 through 2012.

\section{Methods}

Searches for the Golden Swallow were initiated in 1994 as an adjunct to field studies on Swainson's Warbler Limnothlypis swainsonii (Graves 1996, Winker and Graves 2008) and streamertail hummingbirds, Trochilus polytmus and T. scitulus in eastern Jamaica (Graves 2009b, c, Lance et al. 2009, McCormack et al. 2011). I logged 2I field days in the Port Royal Mountains in the vicinity of Hardwar Gap, St. Andrew and Portland parishes (2-10 February 1995, 5-15 March 1996, 4 April 2006), 7o field days in the Blue and John Crow mountains, Portland and St. Thomas parishes (7-10 December 1994, 27-31 March 2003, 31 October-18 November 2003, 11-24 February 2004, 2-15 December 2005, 16-29 March 2006), 12 field days in Cockpit Country, Trelawny and St. Ann parishes (30 March-1 April 2006, 20-28 February 2008), and 4 days on Portland Ridge, Clarendon Parish (29 February-3 March 2008).

I initiated a standardised search effort for the Golden Swallow in December 2008 in conjunction with an island-wide survey of the endemic Jamaican Crow Corvus jamaicensis (Graves 2009a). Censuses were conducted during the non-breeding season (late November through mid-December) when Golden Swallows are believed to move to lower altitudes (Osburn 1860, Wetmore and Swales 1931, Keith et al. 2003). Point count censuses ( $n=1,281$ sites) for aerial insectivores were conducted on 68 field days: 4-16 December 2008 (13 field days), 3-16 December 2009 (14 field days), 2-15 December 2010 (14 field days), 30 November-15 December 2011 (16 field days), and 30 November-10 December 2012 (11 field days). Censuses were conducted island wide, but geographic coverage was concentrated in the central highlands, including relatively dense sampling in Trelawny Parish where Golden Swallows were frequently reported from the mid-1950s through to 1982 (Fig. I).

Census sites were selected in consideration of several prioritised factors. First, all censuses were conducted at sites with at least $15 \%$ canopy cover, loosely defined, within a $300 \mathrm{~m}$ radius of the census point, with at least some trees reaching $10 \mathrm{~m}$ in height. Secondary factors for site selection included 


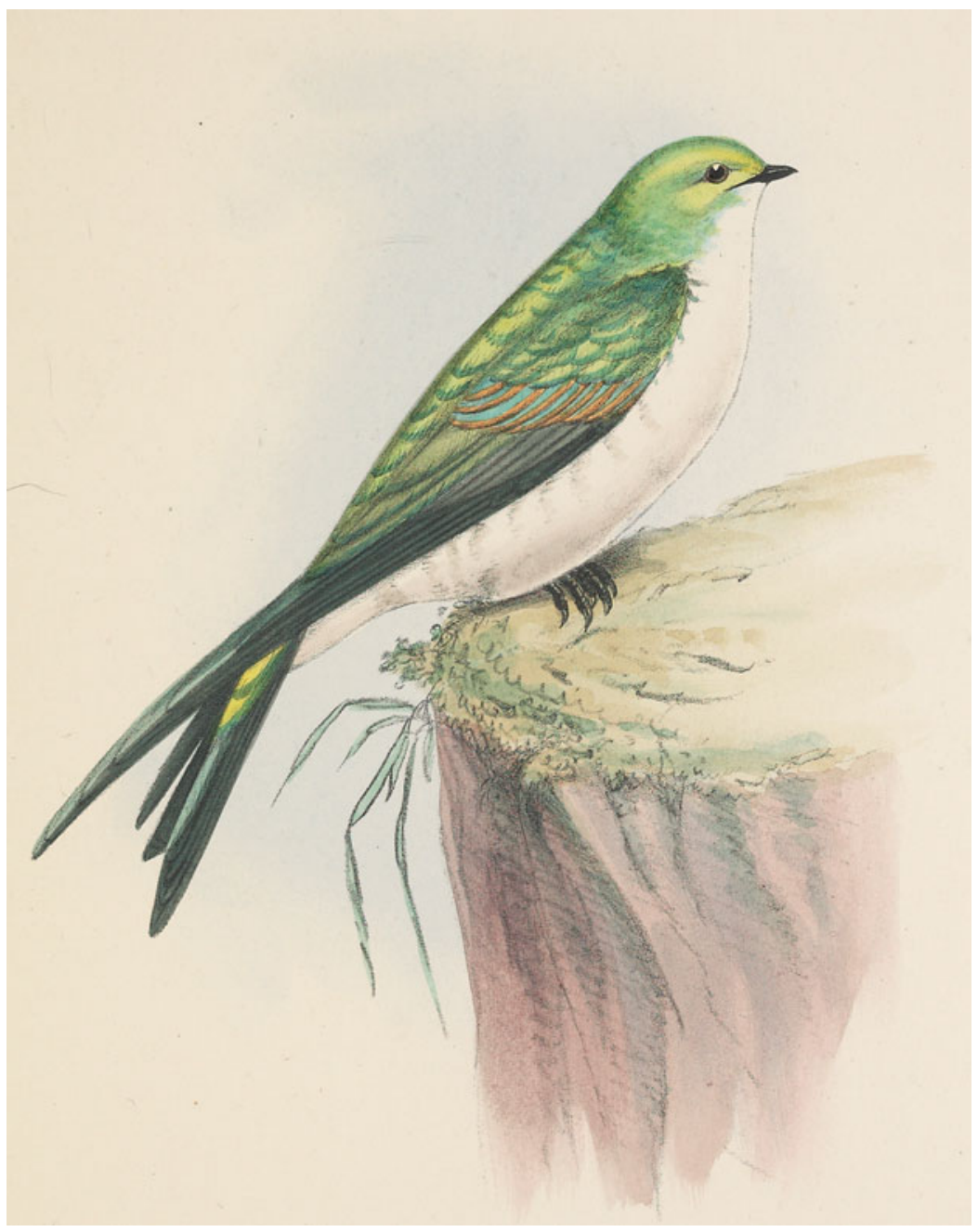

Figure 1. Lithograph of Golden Swallow from Plate 12 of Illustrations of the Birds of Jamaica (Gosse 1849).

road safety, cultural sensitivity, good sight lines, and distance from other census sites (minimum distance $>0.7 \mathrm{~km}$ ). Census sites were located along paved roads, unimproved roads accessible with four-wheel drive vehicles, and along foot trails. Surveyed habitat included wet limestone forest, dry limestone forest, lower montane rain forest, mangrove forest, residential gardens and orchards, shaded coffee plantations, pasturelands with scattered old growth trees, church yards, ruinate woodland, and patchworks of secondary woodland, sugar cane, banana and coconut plantations, bamboo, agricultural scrub, and pasture. No censuses were conducted in plantation monocultures of sugarcane or in arid scrub lacking trees of sufficient stature ( $>10 \mathrm{~m}$ in height) along the southern coast. Ad hoc searches were conducted during several thousand kilometres of driving between census sites and on long distance trips though habitat that was outwardly unsuitable for swallows on the southern coastal plain.

Aerial foraging and large home range size of swallows and swifts present both advantages and challenges during censuses. Foraging swifts and swallows can be detected and identified at great distances (400-60o $\mathrm{m}$ ) but census periods that are too brief may be insufficient to detect locally 
nesting individuals that range widely. At each census site, two observers (G. R. Graves and B. D. Schmidt) used Iox Zeiss binoculars to identify all aerial insectivores observed during a 5 min period. This time interval was generally sufficient for several $360^{\circ}$ scans of the visible horizon. If aerial insectivores were observed during the census period, additional time at the end of the census period was taken to count individuals. Censuses were conducted from oph15 until 15h45. Habitat photographs were taken at each census site. Altitude (m) and geographic coordinates of census sites were recorded with hand-held GPS receivers.

I examined the incidence of co-occurrence of swallows and swifts observed during censuses with the C-score (Stone and Roberts 1990), a quantitative index defined as $\left(R_{i}-S\right) \times\left(R_{j}-S\right)$ where $R_{i}$ and $R_{j}$ represent the total number of occurrences of species ${ }_{i}$ and ${ }_{j}$, respectively, and $\mathrm{S}$ is the number of shared occurrences. The average $\mathrm{C}$-score, calculated over all unique species pairs summarises the pattern of co-occurrence as a single metric. The larger the C-score, the fewer incidents of co-occurrence among pairs of species. Because swifts and swallows are highly mobile, expected occurrences of species were considered equiprobable across all census sites. I used a fixed-equiprobable null model which exhibits better statistical properties for matrices with few species and equiprobable sites than the standard fixed-fixed model (Gotelli 2000). Analyses were conducted in the co-occurrence module of EcoSim Version 7.0 (Gotelli and Entsminger 2001), with fixed row sums, equiprobable column sums, and retained degenerate matrices.

\section{Results}

Census sites were located from sea level to $1,232 \mathrm{~m}$, although most sites occurred at lower altitudes: ( ) o-100 $\mathrm{m}(n=422$ sites); (ii) 101-300 $\mathrm{m}(n=702$ sites); and (iii) $>300 \mathrm{~m}(n=157$ sites). Aerial insectivores were sparsely distributed and observed at only 68 census sites $(5.3 \%$ of total). No Golden Swallows or other species of Tachycineta were observed (Table 2). Cave Swallow Petrochelidon fulva was the most common and widely distributed aerial insectivore (recorded at 38 sites). White-collared Swift Streptoprocne zonaris and Antillean Palm Swift Tachornis phoenicobia were recorded at 15 and 33 sites, respectively. Aerial insectivores cooccurred more frequently than expected by chance (observed C-score $=441.7$; mean and standard deviation of simulated C-scores $=737.4+26.0 ; P<0.00001)$. I dissected the overall $\mathrm{C}$-score by examining the co-occurrence pattern for each pair of species. The aggregate pattern was driven by the significant pairwise co-occurrences of Cave Swallow and Antillean Palm Swift (observed C-score $=456.0$; mean and standard deviation of simulated C-scores $=$ $1186.7 \pm 65.7 ; P<0.00001$ ), and Cave Swallow and White-collared Swift (observed C-score $=$ 374.0; mean and standard deviation of simulated C-scores $=547.3 \pm 33.2 ; P<0.0004)$. In contrast, the Antillean Palm Swift and White-collared Swift did not exhibit a significant pattern of co-occurrence (observed C-score $=495.0$; mean and standard deviation of simulated C-scores $=477.3 \pm 27.9 ; P=0.67)$. Two additional species, Barn Swallow Hirundo rustica and Northern Rough-winged Swallow Stelgidopteryx seripennis, were observed in the Black River Morass, on the coastal plain of St. Elizabeth Parish, during the census period (30 November-16 December) but were not recorded on any of the standardised censuses.

Table 2. Aerial insectivores observed at 1,281 census sites in Jamaica (30 November-16 December, 2008-2012).

\begin{tabular}{lll}
\hline Species & $\begin{array}{l}\text { Number of census } \\
\text { sites observed }\end{array}$ & $\begin{array}{l}\text { Number observed per } \\
\text { occupied site; range }(\bar{x} \pm \text { SD })\end{array}$ \\
\hline Cave Swallow Petrochelidon fulva & 38 & $1-150(12.3 \pm 24.8)$ \\
White-collared Swift Streptoprocne zonaris & 15 & $1-95(28.5 \pm 35 \cdot 5)$ \\
Antillean Palm Swift Tachornis phoenicobia & 33 & $1-25(4.3 \pm 6.0)$ \\
\hline
\end{tabular}




\section{Discussion}

\section{Factors responsible for population decline}

Most historical accounts of the Golden Swallow in Jamaica mentioned locations and dates but little about nesting biology or natural history. By the time conservationists and birders expressed concern about its conservation status (King 1981, Downer 1982), the swallow was already too rare to reliably find, much less study. The reasons behind the collapse of Golden Swallow populations in Jamaica are obscure and are likely to remain so. However, recent observations of the declining Golden Swallow population in Hispaniola provide insight into the factors that may have contributed to the present situation in Jamaica.

Several authors suggested that the combination of logging of pine and broadleaf forests and predation by introduced mammals may be responsible for the population declines of Golden Swallow in Hispaniola (Keith et al. 2003, Townsend 2006, Townsend et al. 2008). Swallows construct nests 8-16 m above the ground in woodpecker holes and natural cavities in trees (Wetmore and Swales 1931, Rimmer et al. 2005, Townsend et al. 2008), in crevices under roof tiles or in the thatched roofs of huts (Wetmore and Lincoln 1933), and in crevices closer to the ground in abandoned bauxite mines (Fernandez and Keith 2003, Townsend et al. 2008). Observations of nesting in the eaves and roofs of houses and barns indicate that the species is not innately adverse to human presence in rural landscapes (Osburn 1859b, March 1863, Wetmore and Swales 1931). Townsend et al. (2008) hypothesized that the scarcity of nest cavities in pine forests in the Dominican Republic was driving swallows to nest in crevices in the vertical walls of abandoned bauxite mines, where predation rates were high.

Habitat destruction has been mentioned as a factor in the decline of Jamaican populations of the Golden Swallow (Birdlife International 2013), but there is little direct evidence to support this hypothesis. For example, the swallow has disappeared from the Cockpit Country and the higher slopes of the Blue Mountains where much mature forest remains. Furthermore, the Jamaican Woodpecker Melanerpes radiolatus, the principal cavity-excavating species in Jamaica, is relatively common in forested landscapes, including taller second growth and gardens throughout the island (Gosse 1847, March 1863, Haynes-Sutton et al. 2009) and provides numerous potential swallow nest cavities. A scarcity of suitable nesting habitat does not therefore appear to be a pertinent factor in the gradual range retraction and final disappearance of the Golden Swallow in Jamaica.

Chronic predation by introduced mammals is a more viable hypothesis for the Golden Swallow's extirpation in Jamaica. The small Indian mongoose Herpestes auropunctatus was introduced in Jamaica in 1872 to control surging black rat Rattus rattus populations in sugarcane plantations (Espeut 1882). The mongoose spread quickly and was credited for the extinction of the Jamaican Petrel Pterodroma caribbaea and Jamaican Pauraque Siphonorhis americanus before the end of the $19^{\text {th }}$ century (Bangs and Kennard 1920). Most avian species believed to have been affected by the mongoose in the Caribbean either nest or forage near the ground (Wetmore 1927). The mongoose possesses modest climbing ability and has been observed entering a Golden Swallow nest built $2 \mathrm{~m}$ above the ground in a bauxite mine in the Dominican Republic (Townsend 2006). In fact, half of the six swallow nests in bauxite mines (0.3-5.0 $\mathrm{m}$ above ground) were destroyed by mammalian predators (Townsend et al. 2008). This and other anecdotal observations of climbing ability and stomach contents of mongooses in the Caribbean indicate that it is a formidable predator of songbird nests built relatively close to the ground (Nellis and Everard 1983, Engeman et al. 2006, Lewis et al. 2011).

The cavity-nesting Golden Swallow was more likely to have been affected by the introduced black rat, which is an accomplished climber of trees and cliff faces (Worth 1950, Wingate 1964, Atkinson 1985, Moors et al. 1992). Rats were implicated in the mortality of 5 of 53 radio-tagged Bicknell's Thrushes Catharus bicknelli in the Dominican Republic (Townsend et al. 2009) and are probably significant predators of nests and adults of songbirds throughout the Caribbean (Atkinson 1985, Engeman et al. 2006, Townsend et al. 2008, 2009). 
James Bond suggested that interspecific competition for nesting cavities with the Eurasian Starling Sturnus vulgaris may have had a negative effect on swallow populations (Bond 1961). However, the Golden Swallow was already in decline in Jamaica when the starling was introduced in 1904 at Fort George, St. Mary Parish (The Daily Gleaner 1904). At present, starlings are relatively uncommon in Jamaica (Haynes-Sutton et al. 2009) and are rarely observed in the traditional Golden Swallow sites in Trelawny Parish or in the Blue Mountains. Similarly, the cavity nesting Caribbean Martin Progne dominicensis is thinly distributed on the coastal plain in Jamaica and is not known to nest in areas formerly occupied by the Golden Swallow.

\section{Conservation status}

Current IUCN guidelines recommend classifying a species as extinct only after exhaustive surveys of the historic range, in appropriate habitat, at the appropriate time, fail to record an individual (IUCN 2012). However, what constitutes "exhaustive" is quantitatively vague. In practice, avian extinction is generally inferred probabilistically from analyses of the temporal distribution of documented occurrences (Solow 2005, Rivadeneira et al. 2009, Elphick et al. 2010). Analysis of survey effort and the generation of explicit stopping rules for searches of putatively extinct species are less frequently conducted (Gotelli et al. 2012). In this case, it is questionable whether statistical inference models can be effectively applied to the terminal sequence of Golden Swallow sightings in Jamaica because of the poor and sporadic documentation of sight records. What can be said is that the string of sightings in the last known redoubt for the species in Trelawny Parish abruptly ceased after 1982 .

Several factors suggest that the Jamaican population of the Golden Swallow is close to extinction, if not already extinct. First, Jamaica is a prime international destination for birding (HaynesSutton et al. 2009). More than a dozen ecotourism companies currently offer birding tours in Jamaica, making it one of the more intensively birded areas in the West Indies. The last known strongholds of the species in Trelawny Parish are often included in birding itineraries (e.g. 12-24 birders visit Windsor annually, M. Schwartz in litt. 2013). In any case, the search effort has been at least as good in recent years as it was in the 1960s when the swallow was still regularly observed at Windsor.

A second factor is that all swallows are diurnal aerial foragers which facilitates the detection and tracking of relatively small populations at continental scales (Evans and Bouwman 2010). The small and localised populations of Golden Swallows on Hispaniola are regularly observed and

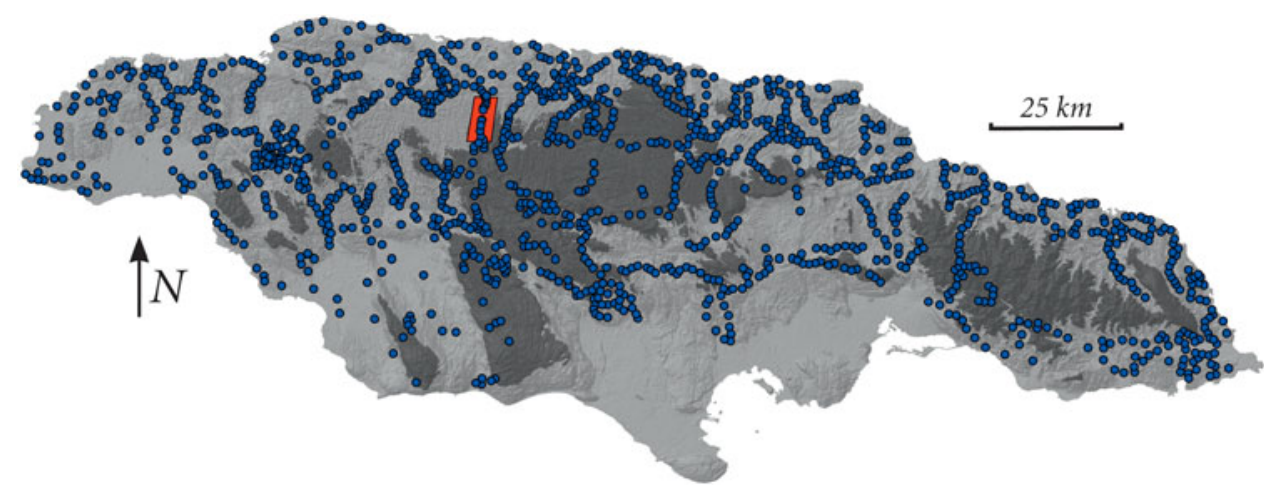

Figure 2. Standardised census sites (blue circles) for Golden Swallows in Jamaica $(n=1,281)$. Red block indicates the Barbecue Bottom Road where sight records were made through 1982. The absence of census sites on the south-central side of the island largely reflects the absence of appropriate habitat. Dark gray shading represents areas $>500 \mathrm{~m}$. 
mated pairs are highly conspicuous as they forage and perform aerial displays in their breeding territories (Rimmer et al. 2005, Townsend et al. 2008). A resident population of Golden Swallows in Jamaica would be difficult to overlook for decades. The lack of documented sight records since the early 1980s, combined with the failure of recent standardised searches, suggest that the Jamaican populations have been extirpated.

\section{Recommendations}

Searches for the Jamaican Golden Swallow should be continued for another two decades before it is declared extinct, in accordance with the 50-year rule formerly used by the IUCN. Plans to translocate the Hispaniolan subspecies to Jamaica (Townsend et al. 2008) should be postponed until the 50 years have elapsed since the 1982 sighting. In the interim, searches should focus on two areas that historically supported swallow populations and that still contain substantial amounts of forest-Trelawny Parish and the Port Royal and Blue Mountains (Fig. 3). Possible sightings should be documented through photography to preclude confusion with other species of Tachycineta swallows. Should a Golden Swallow be sighted in Jamaica, the possibility of
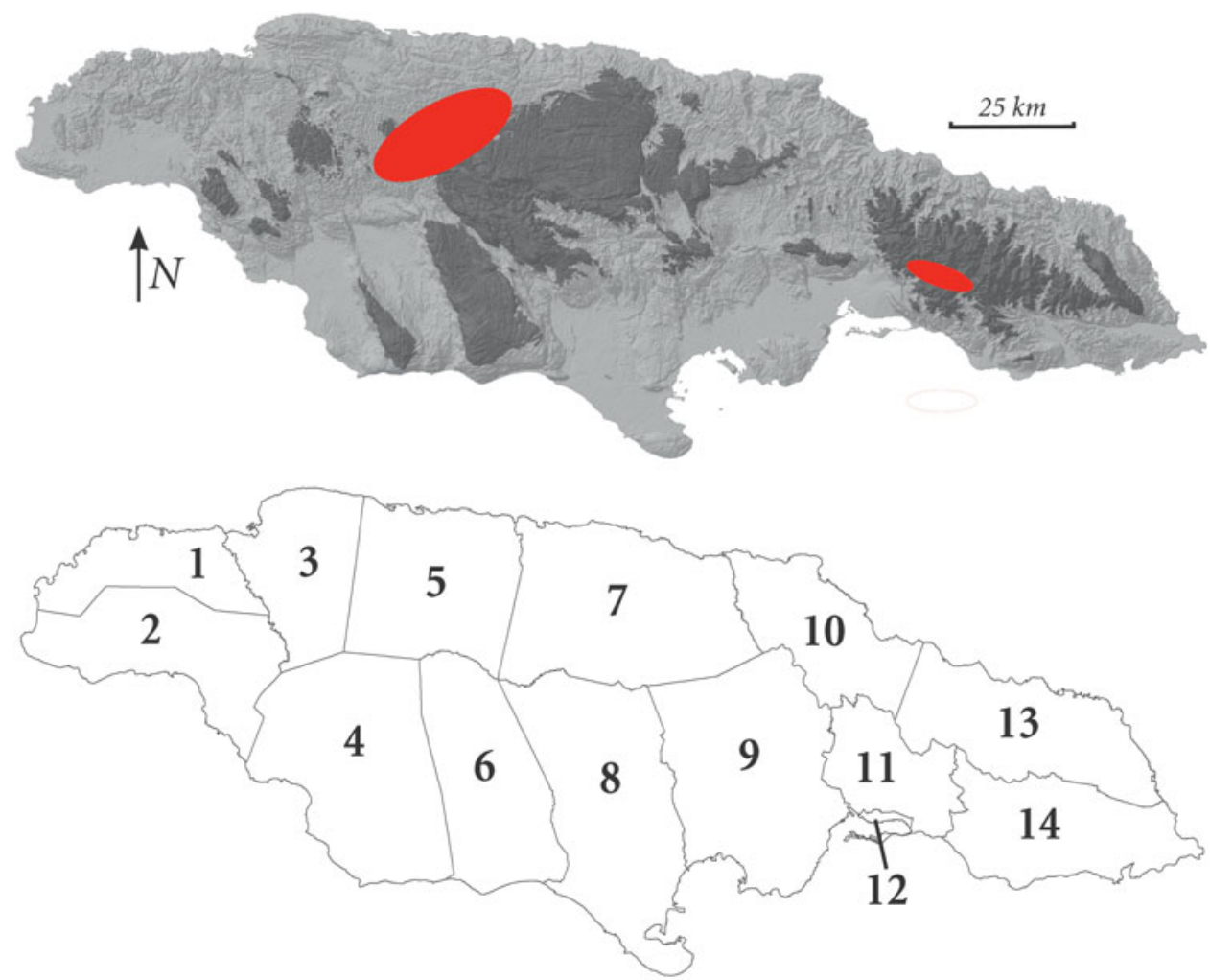

Figure 3. (Top panel) Searches for Golden Swallow in Jamaica should focus on two regions that historically supported swallow populations and that still support substantial amounts of forest: Trelawny Parish (left ellipse extending from Quick Step to Stewart Town); and (2) areas above $700 \mathrm{~m}$ in Port Royal and Blue Mountains (right ellipse extending from Hardwar Gap to Hagley Gap). (Lower panel) Jamaican parishes: (1) Hanover; (2) Westmoreland; (3) St. James; (4) St. Elizabeth; (5) Trelawny; (6) Manchester; (7) St. Ann; (8) Clarendon; (9) St. Catherine; (10) St. Mary; (II) St. Andrew; (12) Kingston; (13) Portland; (14) St. Thomas. 
hurricane-blown individuals from Hispaniola should not be discounted. Unfortunately, the two subspecies may not be distinguishable from in-flight photographs.

\section{Acknowledgements}

Brian Schmidt was an indispensable participant in the aerial insectivore censuses and supplied the base maps. Kim Bostwick (Cornell University Museum of Vertebrates), Mike Brooke (Cambridge University Museum of Zoology), Ben Marks (Field Museum), Brad Millen (Royal Ontario Museum), Robert Prys-Jones and Hein van Grouw (Natural History Museum, formerly British Museum of Natural History), Tony Parker (National Museums Liverpool), Jeremiah Trimble (Museum of Comparative Zoology, Harvard University), and Paul Sweet, Tom Trombone and Mary LeCroy (American Museum of Natural History) provided information on swallow specimens in their care. Catherine Levy and Jim Wiley provided additional information about the Golden Swallow in Jamaica. Susan Koenig and Mike Schwartz (Windsor Research Centre) and Catherine Levy (Kingston) provided critical logistical support. Nick Gotelli gave advice on EcoSim. Catherine Levy, Susan Koenig, Justin Proctor, Jason Townsend, and three anonymous reviewers critiqued earlier drafts of the manuscript. Ellen Alers (Smithsonian Institution Archives) and Catherine Levy helped with W. T. March correspondence. Leslie Overstreet of the Joseph F. Cullman 3rd Library of Natural History (Smithsonian Institution Libraries) provided a digital scan of the Gosse lithograph. This paper is dedicated to Errol Francis (1950-2011) for his contributions to Jamaican science. I am grateful to them all. Fieldwork was supported by the Alexander Wetmore and the James Bond funds of the Smithsonian Institution.

\section{References}

Atkinson, I. A. E. (1985) The spread of commensal species of Rattus to oceanic islands and their effects on island avifaunas. Pp. 35-81 in P. J. Moors, ed. Conservation of island birds: case studies for the management of threatened island species. Cambridge, UK: International Council for Bird Presevation. (ICBP Technical Publication No. 3).

Bangs, O. and Kennard, F. H. (1920) A list of the birds of Jamaica. Kingston, Jamaica: Government Printing Office.

Birdlife International (2013) Species factsheet: Tachycineta euchrysea. Downloaded from http://birdlife.org on 15 February 2013.

Bond, J. (1936) Birds of the West Indies. Philadelphia, USA: The Academy of Natural Sciences of Philadelphia.

Bond, J. (1940) Check-list of birds of the West Indies. Philadelphia, USA: Academy of Natural Sciences of Philadelphia.

Bond, J. (1956) Check-list of birds of the West Indies. Fourth edition. Philadelphia, USA: Academy of Natural Sciences of Philadelphia.

Bond, J. (1961) Extinct and near extinct birds of the West Indies. New York, USA: PanAmerican Section, International Council for Bird Preservation.
Browne, P. (1756) The civil and natural history of Jamaica. London: Printed for the author, and sold by T. Osborne and J. Shipton.

Downer, A. (1982) Is the Golden Swallow declining? Gosse Bird Club Broadsheet 39: 13.

Downer, A. and Sutton, R.. (1972) Birds of the Cockpit Country. Gosse Bird Club Broadsheet 19: 12-13.

Elphick, C. S., Roberts, D. L. and Reed, J. M. (2010) Estimated dates of recent extinctions for North American and Hawaiian birds. Biol. Conserv. 143: 617-624.

Engeman, R., Whisson, D., Quinn, J., Cano, F., Quinones, P. and White, T. H. (2006) Monitoring invasive mammalian predator populations sharing habitat with the critically endangered Puerto Rican Parrot Amazona vittata. Oryx 40: 95-102.

Espeut, W. B. (1882) On the acclimatization of the Indian mungoos in Jamaica. Proc. Zool. Soc. London 50: 712-714.

Evans, S. W. and Bouwman, H. (2010) Historical and current distribution, population size and possible migration routes of the Blue Swallow Hirundo atrocaerulea in Africa. Bird Conserv. Internatn. 20: 240-254. 
Fernandez, E. M. and Keith, A. R. (2003) Three unusual bird nests from the Dominican Republic. J. Caribbean Ornithol. 16: 73-74.

Gosse, P. H. (1847) The birds of Jamaica. London, UK: Bentley, Wilson and Fley.

Gosse, P. H. (1849) Illustrations of the birds of Jamaica. London, UK: J. Van Voorst.

Gotelli, N. J. (2000) Null model analysis of species co-occurrence patterns. Ecology 81: 2606-2621.

Gotelli, N. J. and Entsminger, G. L. (2001) EcoSim: Null models software for ecology. Version 7.o. Acquired Intelligence Inc. \& Kesey-Bear. http://homepages.together.net/ $\sim$ gentsmin/ecosim.htm

Gotelli, N. J., Chao, A., Colwell, R. K., Wang, W. H. and Graves, G. R.. (2012) Specimenbased modeling, stopping rules, and the extinction of the Ivory-billed Woodpecker. Conserv. Biol. 26: 47-56.

Graves, G. R. (1996) Censusing wintering populations of Swainson's Warbler: surveys in the Blue Mountains of Jamaica. Wilson Bull. 108: 94-103.

Graves, G. R. (2009a) Communal roosting of the Jamaican Crow (Corvus jamaicensis) J. Caribbean Ornithol. 22: 48-51.

Graves, G. R. (2009b) Ontogeny of bill color in streamertail hummingbirds. J. Caribbean Ornithol. 22: 44-47.

Graves, G. R. (2009c) Skeletal correlates of body weight in the Black-billed Streamertail (Trochilus scitulus) of Jamaica. Caribbean J. Sci. 45: 1-4.

Haynes-Sutton, A., Downer, A. and Sutton, R. (2009) A photographic guide to the birds of Jamaica. Princeton, New Jersey: Princeton University Press.

IUCN (2012) IUCN Red List of Threatened Species. Version 2012.2. www.iucnredlist.org, Downloaded on o8 March 2013.

Keith, A. R., Wiley, J. W., Latta, S. C. and Ottenwalder, J. A. (2003) The birds of Hispaniola. Tring, Hertfordshire, UK: British Ornithologists' Union and British Ornithologists' Club.

Kidd, E. R. G. (1964) A day at Windsor, Trelawny. Gosse Bird Club Broadsheet 2: 8.

Kidd, E. R. G. (1965) Return visit to Windsor, Trelawny. Gosse Bird Club Broadsheet 4: 7.
King, W. B. (1981) Endangered birds of the world: the ICBP bird red data book. Washington, DC: Smithsonian Institution Press.

Lance, S. L., Hagen, C., Glenn, T. C., Brumfield, R. T., Stryjewski, K. F. and Graves, G. R. (2009) Fifteen polymorphic microsatellite loci from Jamaican streamertail hummingbirds (Trochilus). Conserv. Genet. 10: 1195-1198.

Lewis, D. S., van Veen, R. and Wilson, B. S. (2011) Conservation implications of small Indian mongoose (Herpestes auropunctatus) predation in a hotspot within a hotspot: the Hellshire Hills, Jamaica. Biol. Invasions 13: 25-33.

March, W. T. (1863) Notes on the birds of Jamaica. Proc. Acad. Nat. Sci. Philadelphia 15: 283-304.

McCormack, J. E., Maley, J. M., Hird, S. M., Derryberry, E. P., Graves, G. R. and Brumfield, R. T. (2011) Next-generation sequencing reveals phylogeographic structure and a species tree for recent bird divergences. Mol. Phylogen. Evol. 62: 397-406.

Moors, P. J., Atkinson, I. A. E. and Sherley, G. H. (1992) Reducing the rat threat to island birds. Bird Conserv. Internatn. 2: 93-114.

Nellis, D. W. and Everard, C. O. R. (1983) The biology of the mongoose in the Caribbean. Studies on the fauna of Curaçao and other Caribbean Islands 195: 1-162.

Osburn, W. (1859a) Notes on the birds of Jamaica. The Zoologist 17: 6368-6373.

Osburn, W. (1859b) Notes on the mountain birds of Jamaica. The Zoologist 17: 6709-6721.

Osburn, W. (1860) Notes on the mountain birds of Jamaica. The Zoologist 18: 6873-688o.

Raffaele, H., Wiley, J., Garrido, O., Keith, A. and Raffaele, J. (1998) Birds of the West Indies. London, UK: Christopher Helm.

Rimmer, C. C., Townsend, J. M., Townsend, A. K., Fernandez, E. M. and Almonte, J. (2005) Avian diversity, abundance, and conservation status in the Macaya Biosphere Reserve of Haiti. Ornithol. Neotrop. 16: 219-230.

Rivadeneira, M. M., Hunt, G. and Roy, K. (2009) The use of sighting records to infer species extinctions: an evaluation of different methods. Ecology 90: 129239-25100.

Salmon, L. (1964) Violet-green Swallow. Gosse Bird Club Broadsheet 5: 24. 
Scott, W. E. D. (1893) Observations on the birds of Jamaica, West Indies. II. A list of the birds recorded form the island, with annotations. Auk 10: 177-181.

Scott, W. E. D. (1904) The story of a bird lover. New York, USA: MacMillan.

Sladen, F. (1997) Golden Swallow. Gosse Bird Club Broadsheet 68: 31 .

Sloane, $\mathrm{H}$. (1725) A voyage to the islands of Madera, Barbadoes, Nieves, St. Christophers, and Jamaica; with the natural history of the herbs and trees, four-footed beasts, fishes, birds, insects, reptiles, $\mathcal{E}$ c. of the last of those islands. Vol. 2. London, UK: Printed by B. M. for the author.

Solow, A. R. (2005) Inferring extinction from a sighting record. Mathemat. Biosci. 195: 47-55.

Stone, L. and Roberts, A. (1990) The checkerboard score and species distributions. Oecologia 85: 74-79.

Sykes, P. W. (1983) Field notes of a birding holiday on Jamaica. Gosse Bird Club Broadsheet 41: 1-8.

The Daily Gleaner (1904) Five cases of English birds arrived in the steamer Port Antonio yesterday afternoon from England for Mr. R.J. Taylor-Domville of Fort George, St. Mary. 8 October, page 2.

Townsend, J. (2006) Predation of a Golden Swallow (Tachycineta euchrysea) nest by the Indian Mongoose (Herpestes javanicus) in the Sierra de Bahoruco, Dominican Republic. J. Caribbean Ornithol. 19: 108-109.
Townsend, J. M., Garrido, E. and Mejia, D. A. (2008) Nests and nesting behavior of Golden Swallows (Tachycineta euchrysea) in abandoned bauxite mines in the Dominican Republic. Wilson J. Ornithol. 120: 867-871.

Townsend, J. M., Rimmer, C. C., Brocca, J., McFarland, K. P. and Townsend, A. K. (2009) Predation of a wintering migratory songbird by introduced rats: can nocturnal roosting behavior serve as predator avoidance? Condor 111: 565-569.

Wetmore, A. (1927) The birds of Porto Rico and the Virgin Islands: Psittaciformes to Passeriformes. New York: New York Academy of Sciences.

Wetmore, A. and Lincoln, F. C. (1933) Additional notes on the birds of Haiti and the Dominican Republic. Proc. United States Natl. Mus. 82: 1-68.

Wetmore, A. and Swales, B. H. (1931) The birds of Haiti and the Dominican Republic. Washington DC: U.S. Government Printing Office.

Wingate, D. B. (1964) Discovery of breeding Black-capped Petrels on Hispaniola. Auk 81: 147-159.

Winker, K. and Graves, G. R. (2008) Genetic structure of breeding and wintering populations of Swainson's Warbler. Wilson Bull. 120: 433-445.

Worth, C. B. (1950) Field and laboratory observations on roof rats, Rattus rattus (Linnaeus), in Florida. J. Mammal. 31: 293-304.

\section{GARY R. GRAVES}

Department of Vertebrate Zoology, MRC-116, National Museum of Natural History, Smithsonian Institution, P. O. Box 37012, Washington, D.C. 20013-7012 USA, and Center for Macroecology, Evolution and Climate, University of Copenhagen, DK-210o, Copenhagen Ø, Denmark. 